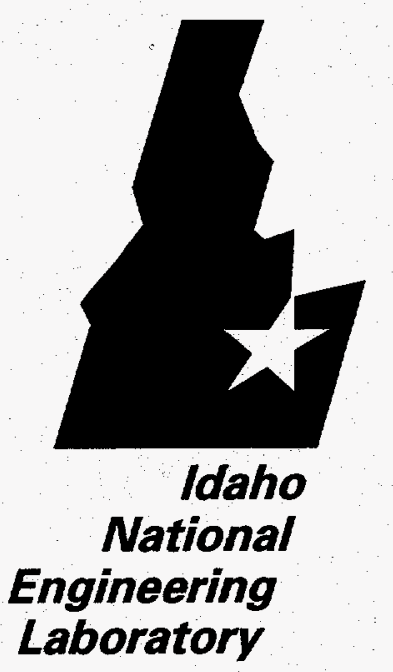

RECEIVED

NOV 211995

OSTI

Functions and Requirements for the INEL Light Duty Utility Arm Sampler End Effector

David P. Pace

Gary E. Barnes

ICPP Document Category II

Laboratory

February 1995

INEL-9/, $\$$ 


\section{Functions and Requirements for the INEL Light Duty Utility Arm Sampler End Effector}

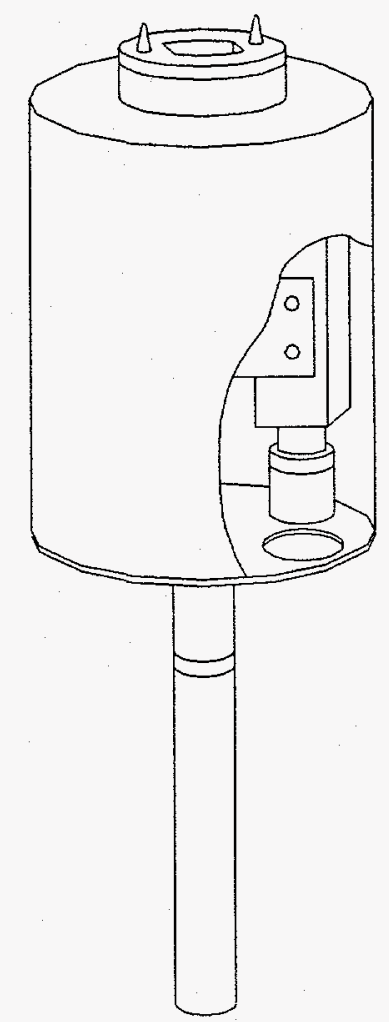

David P. Pace Gary E. Barnes

Published February 1995

Idaho National Engineering Laboratory Lockheed Idaho Technologies Company Idaho Falls, Idaho 83415

\section{Prepared for the}

U.S. Department of Energy

Assistant Secretary for Environmental Management Under DOE Idaho Operations Office

Contract DE-AC07-94ID13223 


\section{DISCLAIMER}

Portions of this document may be illegible in electronic image products. Images are produced from the best available original document. 


\begin{abstract}
This sampler end effector system functions and requirements document defines the system functions that the end effector must perform as well as the requirements the design must meet. Safety, quality assurance, operations, environmental conditions, and regulatory requirements have been considered. The main purpose of this document is to provide a basis for the end effector engineering, design, and fabrication activities. The document shall be the living reference document to initiate the development activities and will be updated as system technologies are finalized.
\end{abstract}

\title{
DISCLAIMER
}

This report was prepared as an account of work sponsored by an agency of the United States Government. Neither the United States Government nor any agency thereof, nor any of their employees, makes any warranty, express or implied, or assumes any legal liability or responsibility for the accuracy, completeness, or usefulness of any information, apparatus, product, or process disclosed, or represents that its use would not infringe privately owned rights. Reference herein to any specific commercial product, process, or service by trade name, trademark, manufacturer, or otherwise does not necessarily constitute or imply its endorsement, recommendation, or favoring by the United States Government or any agency thereof. The views and opinions of authors expressed herein do not necessarily state or reflect those of the United States Government or any agency thereof. 


.




\section{CONTENTS}

ACRONYMS $\ldots \ldots \ldots \ldots \ldots \ldots \ldots \ldots \ldots \ldots \ldots \ldots \ldots \ldots \ldots \ldots \ldots$ iii

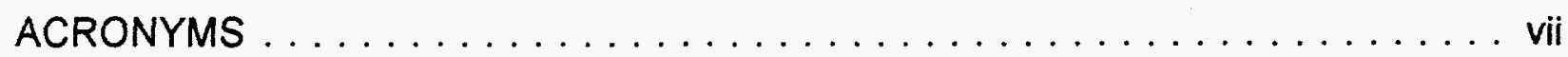

1. INTRODUCTION ....................... 1

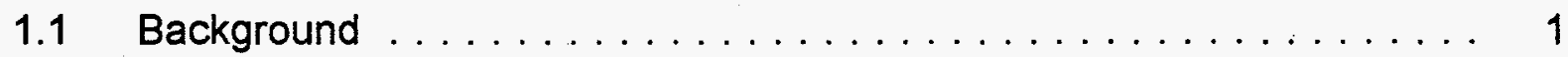

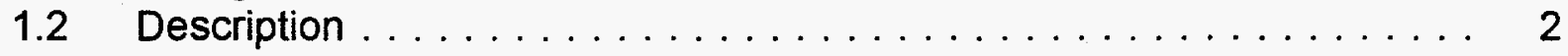

1.3 Purpose ........................... 2

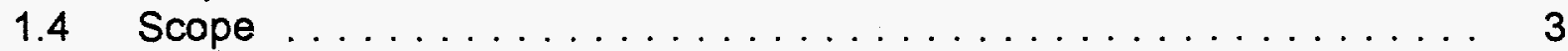

1.5 Definition of Terms ..................... 3

2. FUNCTIONS, REQUIREMENTS, AND ASSUMPTIONS $\ldots \ldots \ldots \ldots \ldots .4$

2.1 General Assumptions . . . . . . . . . . . . . . . . . . . 4

2.2 General Requirements . . . . . . . . . . . . . . . . 4

2.3 In-Tank Equipment Assumptions $\ldots \ldots \ldots \ldots \ldots \ldots \ldots \ldots \ldots$

2.4 In-Tank Requirements . . . . . . . . . . . . . . . . . . . 5

2.5 Sampler End Effector System Control Requirements . . . . . . . . . . . 8

2.6 Sampler End Effector Assumptions . . . . . . . . . . . . . . 10

2.7 Sampler End Effector System Functions . . . . . . . . . . . . . 10

2.8 Sampler End Effector Software Development Requirements . . . . . 10

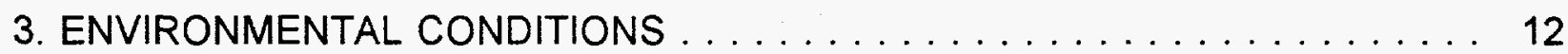

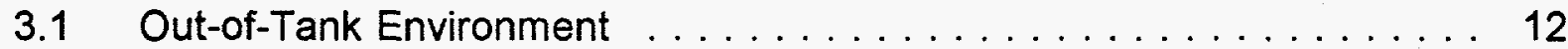

3.2 In-Tank Environment . . . . . . . . . . . . . . . . . . . . . . . 12

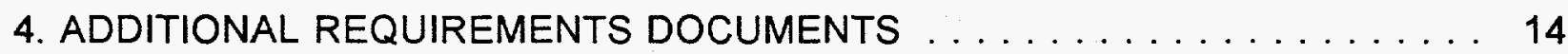

4.1 Structural Materials Properties . . . . . . . . . . . . . . . . . . . 14

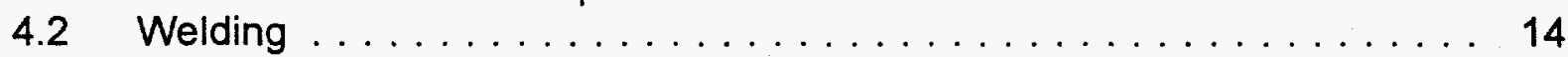

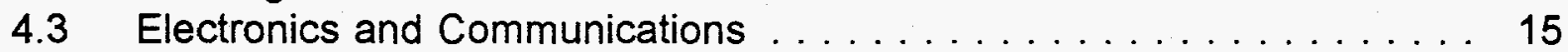

4.4 Electrical ............................. 16

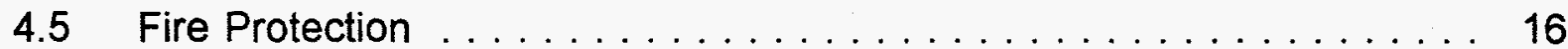

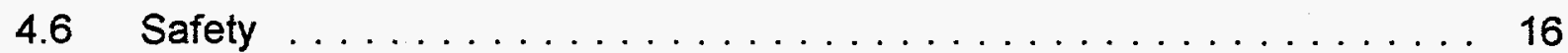

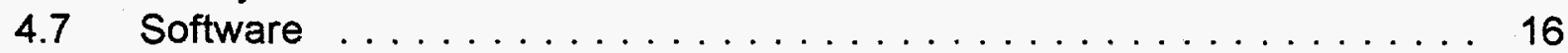

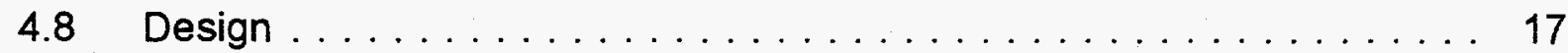

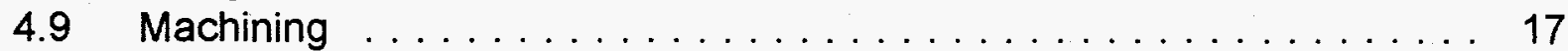

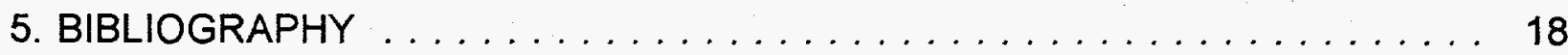

Appendix A - Draft Analysis List . . . . . . . . . . . . . . . . . . . . A-1

Appendix B - Tool Interface Plate . . . . . . . . . . . . . . . . B-1 


\section{Functions and Requirements \\ for the \\ INEL Light Duty Utility Arm \\ Sampler End Effector}

\section{INTRODUCTION}

\section{$1.1 \quad$ Background}

In 1990 the U.S. Department of Energy (DOE) Office of Technology Development initiated the Light Duty Utility Arm (LDUA) program. A major portion of this program addresses stabilization and remediation of dangerous wastes accumulated in underground storage tanks (USTs). The priority of this program is verifying tank structural integrity and characterizing highlevel, mixed waste stored in the storage tanks.

The LDUA, a seven degree of freedom robotic arm with a telescoping vertical deployment mast (see Figure 1), is being developed to obtain this vital data. The LDUA robotic system will provide the capability to perform tank surveillance and inspection, in situ waste characterization, nondestructive evaluation of tank walls to verify tank integrity, tank mapping for modeling, and small-scale retrieval operations in USTs. The Office of Technology Development (EM-50) is sponsoring this work to support Waste Operations (EM-30) missions, including tank safety programs, tank characterization and surveillance assessment, and retrieval and separations technology development.

The objective of the sampler end effector is to retrieve samples of the waste heel for characterization in support of the Tank Farm Heel Removal Project. A secondary objective is to respond to Tiger Team finding WM/CF-5, "Complete robotic inspections of HLLW tanks," where samples need to be taken for sludge monitoring purposes as required by DOE Order $5820.2 \mathrm{~A}$ and to obtain RCRA waste characterization samples as required by $40 \mathrm{CFR}$ 265.13/264.13 and close out WAR 91072-8.

A sampler end effector system will be developed and fabricated at the Idaho National Engineering Lab (INEL) for the LDUA and will incorporate the lessons learned from the sampler end effector developed for the Remote Tank Inspection (RTI) robotic system. The sampler end effector system will include the actual sampler end effector at the end of the robotic arm; any support systems located in the at-tank interface unit; and the display, dataprocessing, and control systems located in the control trailer. The sampler end effector will obtain a sample from the waste heel at the tank bottom and remove it to the transfer systems in a contained form. The sample will then be transported in the transfer system to an analytical lab for waste characterization. Appendix $A$ lists the analysis to be completed. 


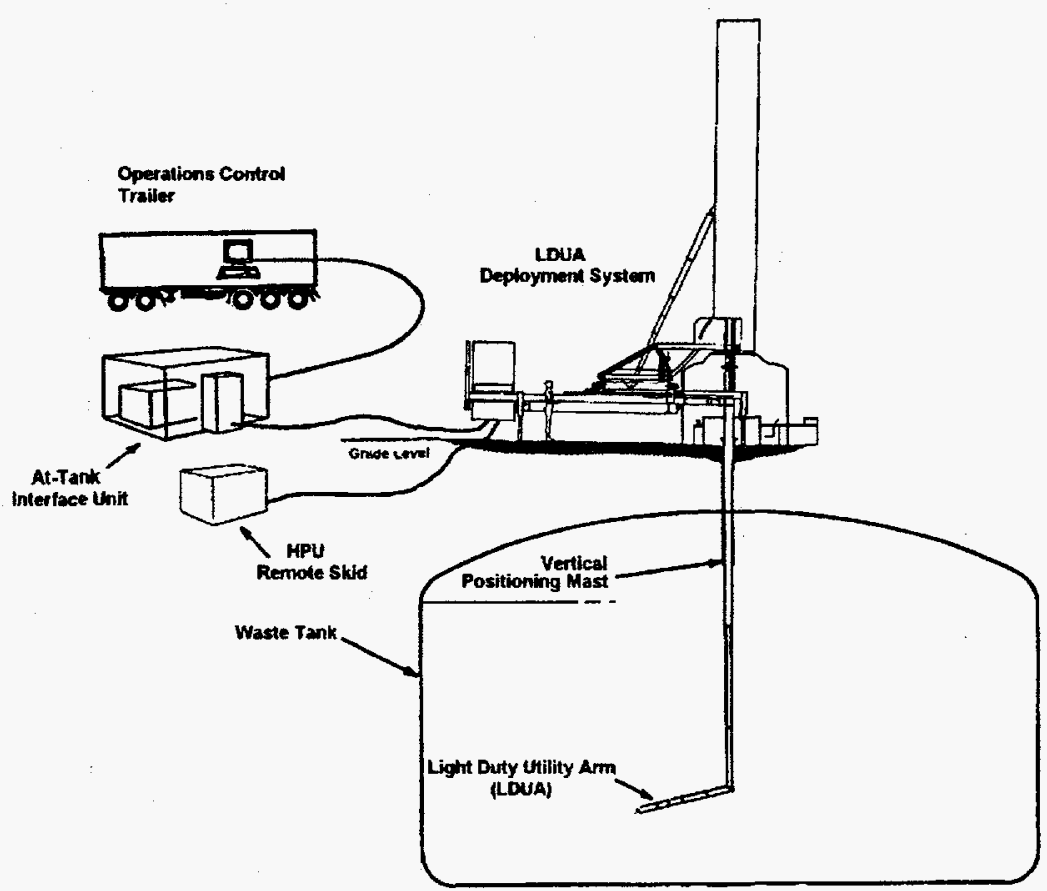

Figure 1. LDUA typical deployment setup.

\subsection{Description}

Section 2 of this document contains the functions and requirements for the sampler end effector system. Safety, quality assurance, operations, and regulatory requirements are included.

Section 3 describes the in-tank and out-of-tank environments that the LDUA integrated system and its end effectors must meet during normal tank farm operations.

Section 4 lists some relevant codes and standards to which the design must comply.

Section 5, "Bibliography," identifies sources containing information significant in the development of this functions and requirements document.

\section{$1.3 \quad$ Purpose}

This document provides the basis for the end effector engineering, design, and fabrication activities. This shall be the reference document to initiate development activities. As system and technologies are finalized, this document will be updated. The basis for the parameters specified herein have been derived from several sources, including the objectives to demonstrate environmental technology and characterization of USTs and their waste contents. 


\subsection{Scope}

The scope of this document includes the overall sampler end effector system requirements and subsystem parameters. It also provides the general guidelines for subsystem interfaces. The design shall include all components for a fully operational stand-alone system that shall include the end effector and the related display and control system hardware and software, both in the at-tank instrument enclosure and the operation control trailer.

\subsection{Definition of Terms}

Function. A function is a description of the task a system, subsystem, or component must perform. It is not a description of the device in any manner, but may establish some of the parameters within which the device must perform.

Requirement. A requirement is a mandatory factor that must be applied or incorporated into the design of the device performing the specified function. It is not a preference and uses the word "shall."

Assumption. An assumption is a basis for a requirement that is taken to be true without necessarily having proof or demonstration. Changes in assumptions may have significant impacts on related requirements. 


\section{FUNCTIONS, REQUIREMENTS, AND ASSUMPTIONS}

\section{$2.1 \quad$ General Assumptions}

The in-tank and out-of-tank environmental conditions listed in Section 3 are assumed to be the extreme ranges.

\subsection{General Requirements}

The sampler end effector system shall be designed and fabricated to

2.2.1 Use human factors, engineering principles, and a modular design approach to ensure ease of assembly, operation, and maintenance.

2.2.2 Meet a 5-to-1 safety factor on ultimate or a 3-to-1 on yield, whichever is more conservative, for all load-bearing components whose failure would result in damaging the tank or loss of parts into the tank, and a 1.5-to-1 safety factor on yield with appropriate dynamic factors for all other components.

2.2.3 Tolerate the in-tank and out-of-tank environmental conditions described in Section 3.

2.2.4 Have a maximum weight of $75 \mathrm{lbs}$ and a maximum moment loading of 1,000 in.-lbs at the end effector and manipulator mating surface including the end effector side of the tool interface plate (TIP) and the sample as part of the load, minimizing weight and moment as much as practical.

2.2.5 Have a maximum exterior-envelope diameter of 10.5 in. during deployment and retraction. The end effector may expand beyond the 10.5-in. range during operation in the tank but must automatically return to less than the 10.5-in. envelope for removal from the tank for any recovery scenarios including damage to the robotic arm, power failure, damage to the end effector, etc.

2.2.6 Have a maximum exterior length of 30 in., including the end effector side of the TIP, excluding the guide pins. Some open space will be available in the TIP for end effector components (see Appendix B for TIP specifics).

2.2.7 Operate under extreme environmental conditions described in Section 3 for up to eight hours of continuous use in worst-case operating parameters without system degradation. 
The end effector systems shall not

2.2.8 Add any quantity of fluids or materials to the USTs for sampler decontamination, sample purging, or other uses, unless the type and amount being added have been approved by appropriate tank farm organizations and the waste management authority.

\subsection{In-Tank Equipment Assumptions}

The radiological and chemical limits listed in Section 3, "Environmental Conditions" will not exceed the maximum levels listed.

\section{$2.4 \quad$ In-Tank Requirements}

The following in-tank requirements apply to end effector system equipment that will operate in the in-tank environment described in Section 3. The systems components in the at-tank interface unit do not have to meet these requirements. The in-tank requirements are in addition to those in Section 2.2, "General Requirements."

In-tank end effector system equipment shall be designed and fabricated to

2.4.1 Withstand in-tank radiation fields that may approach $500 \mathrm{rad} / \mathrm{h}$. The complete system must survive an accumulated dose of $1 \mathrm{x}$ $10^{6} \mathrm{rad}$ without maintenance to any/all systems, subsystems, or components. If these levels cannot be attained, $1 \times 10^{5}$ rad is acceptable with periodic modular replacement of radiationsusceptible components if equipment changeout is sufficiently easy and if replacement is not cost prohibitive.

2.4.2 Minimize any collection points where waste could become trapped (i.e., rivets, protrusions, and crevices).

2.4.3 Ensure all exposed surfaces can withstand repeated decontamination with high-pressure water up to $300 \mathrm{psi}$.

2.4.4 Ensure all exposed surfaces can withstand repeated decontamination by one or more of the following solutions for follow-on cleaning (e.g., Washall and water with temperatures up to $200^{\circ} \mathrm{F}$, Butchers Speedball compound, Radiac Wash compound, 3-to-6 molar nitric acid, 3-to-6 molar oxalic acid, and Turco cleaning compound 4502 at temperatures to $250^{\circ} \mathrm{F}$ ).

2.4.5 Ensure exposed surface finishes are easy to decontaminate. 
2.4.6 Maximize retrievability (i.e., in-tank equipment cannot hang up or become trapped in tank) during both normal and postfailure retrieval. The transition from the end effector to the TIP must be a smooth transition to eliminate retrieval entrapment problems.

2.4.7 Be used in Class 1, Division 1, Group $B$ environments as defined in National Fire Protection Association (NFPA) 70-93 (NFPA 1993 Code 500/501).

2.4.8 Be able to reach between the cooling coils to the maximum expected 3 in. solids waste heel, located on the tank floor, for sampling (see Figure 2 for cooling coil configuration).

2.4.9 Be able to sample to the bottom of the expected 3-in. maximum solids waste heel up to a total sample depth of 18 -in. below the liquid surface.

In-tank equipment shall not

2.4.10 Lose or leave any system components or materials in the tank.

2.4.11 Damage the USTs. 


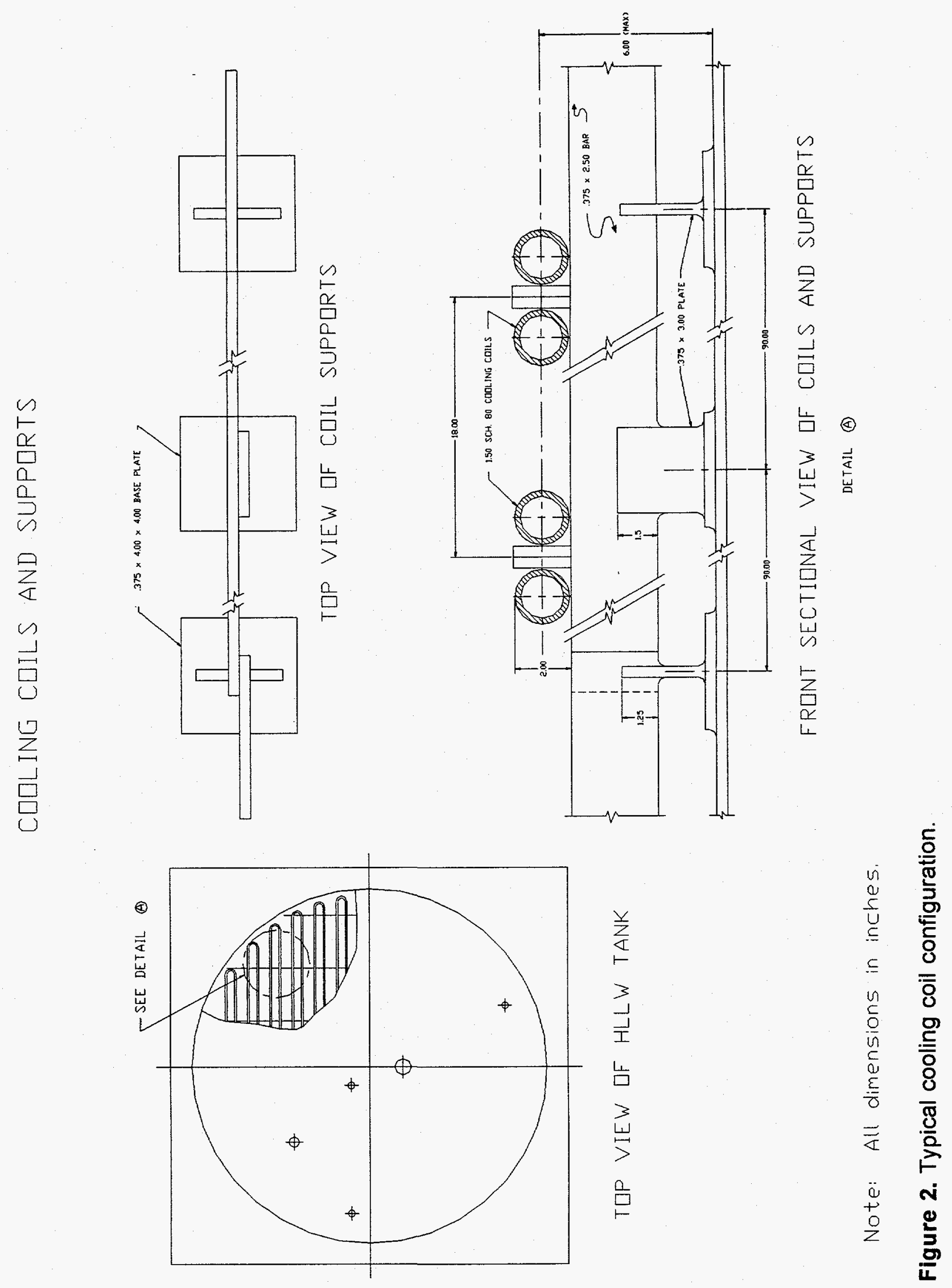




\subsection{Sampler End Effector System Control Requirements}

This section describes the interface requirements for the sampler end effector system with the general LDUA control and data acquisition systems. Figure 3 shows the assumed overall system configuration of the sampler end effector with the LDUA systems.

The sampler end effector system shall be designed to

2.5.1 Interface with the Supervisory Data Acquisition System (SDAS) for supervisory control of the data acquisition cycle. This shall include, but not be limited to,

- Actuation of sample mechanism

- Zoom of the camera lens

- Focus of the camera lens

- Iris control of the camera lens

- Variable control of the lighting system

2.5.2 Utilize the TIP and LDUA wiring for supplying all services and communications from the end effector to the at-tank systems through existing cabling approximately $215 \mathrm{ft}$ in length (see Appendix $B$ for available wiring).

2.5.3 Utilize two fiber cables for control and communication over the $900 \mathrm{ft}$ from the at-tank interface unit to the display and control systems located in the control trailer. More fibers might be made available if critical.

2.5.4 Provide adequate RFI and EMF shielding on all system wiring not provided by the LDUA system.

2.5.5 Use end effector connector pinouts for the LDUA wiring from the TIP to the at-tank enclosure that are compatible with definitions provided by the INEL upon request. 


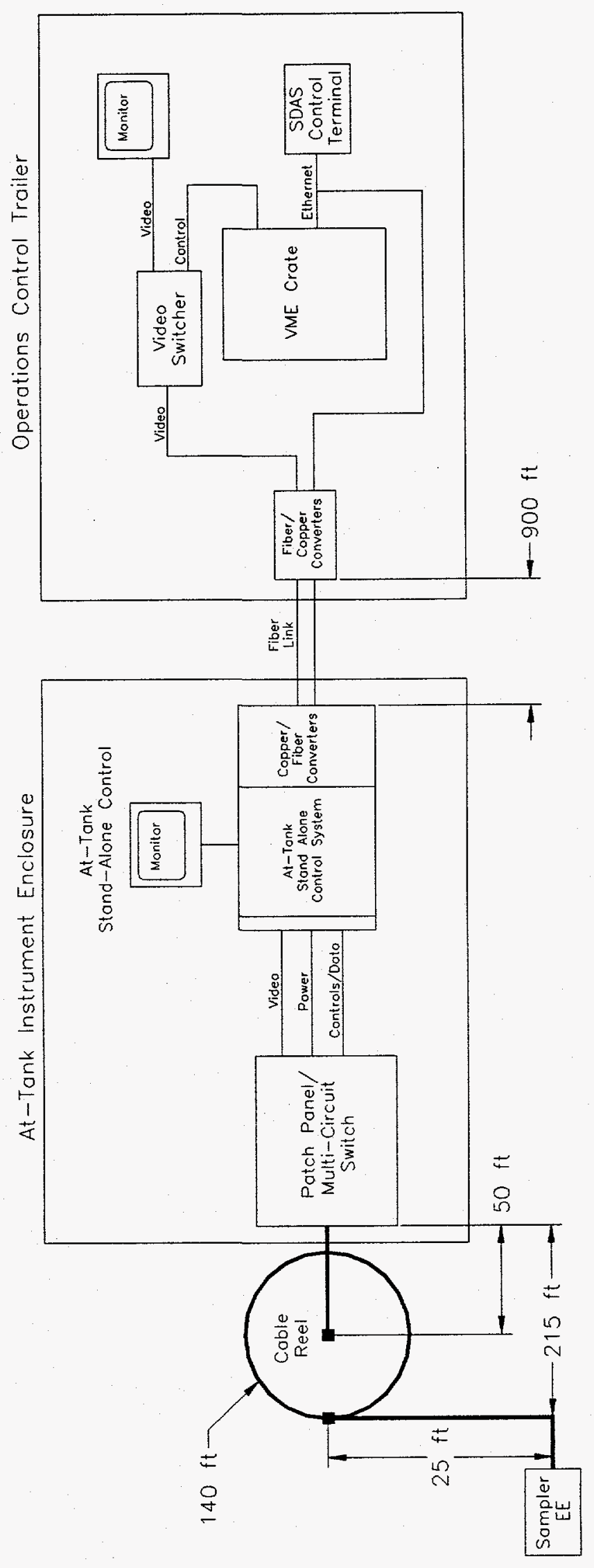

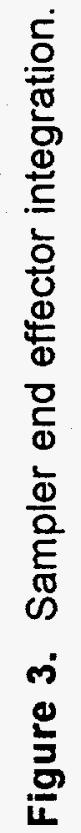




\subsection{Sampler End Effector Assumptions}

The sampler will not be required to sample waste at depths below those specified in Section 2.4.9.

\subsection{Sampler End Effector System Functions}

The sample end effector shall

2.7.1 Obtain adequate sample size necessary for waste analysis characterization, through multiple sampling if needed.

2.7.2 Provide contact compliance with a remote readout of compression distance.

2.7.3 Be able to obtain a mixed solid/liquid sample.

2.7.4 Obtain samples in a minimum of 30 minutes.

2.7.5 Ensure sample is adequately contained during removal to transfer system.

2.7.6 Remotely deposit samples into the transfer system to be determined by the INEL for removal to the analysis lab.

2.7.7 Include a color camera system for general viewing with the following attributes:

- Resolution of 400 lines or greater

- Remote zoom lens control (minimum zoom 6:1)

- Remote iris control

- Remote focus control.

2.7.8 Provide a variable control lighting system capable of supporting system operation within the UST environment without supplemental lighting.

\subsection{Sampler End Effector Software Development Requirements}

Software development must proceed in a traceable, planned, and orderly manner. The following section is intended as a guide for software development, implementation, and validation. All design and implementation activities shall be done internal to the developing organization with involvement of the INEL in the validation stage. 
The design phase shall include

2.8.1 All requirements be specified, documented, and reviewed.

2.8.2 Test plans based on the requirements and design.

2.8.3 Generation of design-based test cases.

2.8.4 Review of the design to ensure all requirements have been addressed.

The implementation phase shall include

2.8.5 Analysis to identify and correct errors.

2.8.6 Development of required documentation.

2.8.7 Examination of source code listings to ensure adherence to coding standards and conventions.

The validation phase shall demonstrate

2.8.8 Software adequately and correctly performs all intended functions for the design-based test cases performed by individuals other than those who designed the software.

2.8.9 Software does not perform any unintended functions.

2.8.10 User documentation is adequate.

2.8.11 An integrated software and hardware test to verify all functionality of software. 


\section{ENVIRONMENTAL CONDITIONS}

This section describes the expected in-tank and out-of-tank environment ranges that the sampler end effector will experience during normal operation and must be designed to tolerate. Figure 4 describes a typical tank at the INEL Tank Farm.

\subsection{Out-of-Tank Environment}

Although the sampler end effector is designed for operation in the tank, the system must operate in the out-of-tank environment during installation and deployment and must be able to be stored under the storage conditions.

3.1.1 Ambient Temperature - Out-of-tank temperatures range from $35^{\circ} \mathrm{F}$ to $120^{\circ} \mathrm{F}$.

3.1.2 Storage temperature - Container temperatures range from $-30^{\circ} \mathrm{F}$ to $150^{\circ} \mathrm{F}$.

3.1.3 Humidity - The relative humidity ranges from 4 to $100 \%$.

\subsection{In-Tank Environment}

3.2.1 The expected maximum radiation field is $500 \mathrm{rad} / \mathrm{h}$ at the solid waste surface.

3.2.2 Temperature - In-tank temperatures range from $45^{\circ} \mathrm{F}$ to $100^{\circ} \mathrm{F}$.

3.2.3 Humidity - The relative humidity ranges up to $100 \%$.

3.2.4 Dust - Some tanks may have airborne abrasive particles.

3.2.5 Chemical - The chemical environment is acidic with high levels of sodium. The maximum acid concentration is 6 molar nitric acid with a $\mathrm{pH}$ of less than 1 . High levels of chloride are also present up to 0.031 molar.

3.2.6 Gases - The tanks may contain organics that could produce flammable gases.

3.2.7 Pressure - The tank internal pressure differential is 2.5 in w.g. vacuum to 5 in w.g. of pressure.

3.2.8 Solids - The maximum total amount of solids expected in the heel for each tank is estimated at $9,000 \mathrm{~kg}$ for a 3 -in. heel. Seventyfive percent of the weight of the particles is estimated to be larger than $45 \mu$ with a density of $3.0 \mathrm{~g} / \mathrm{mL}$. Particles sizes smaller then $45 \mu$ have a density of $5.5 \mathrm{~g} / \mathrm{mL}$ and account for $25 \%$ of the total weight. The solids are expected to be in a sandy form. 


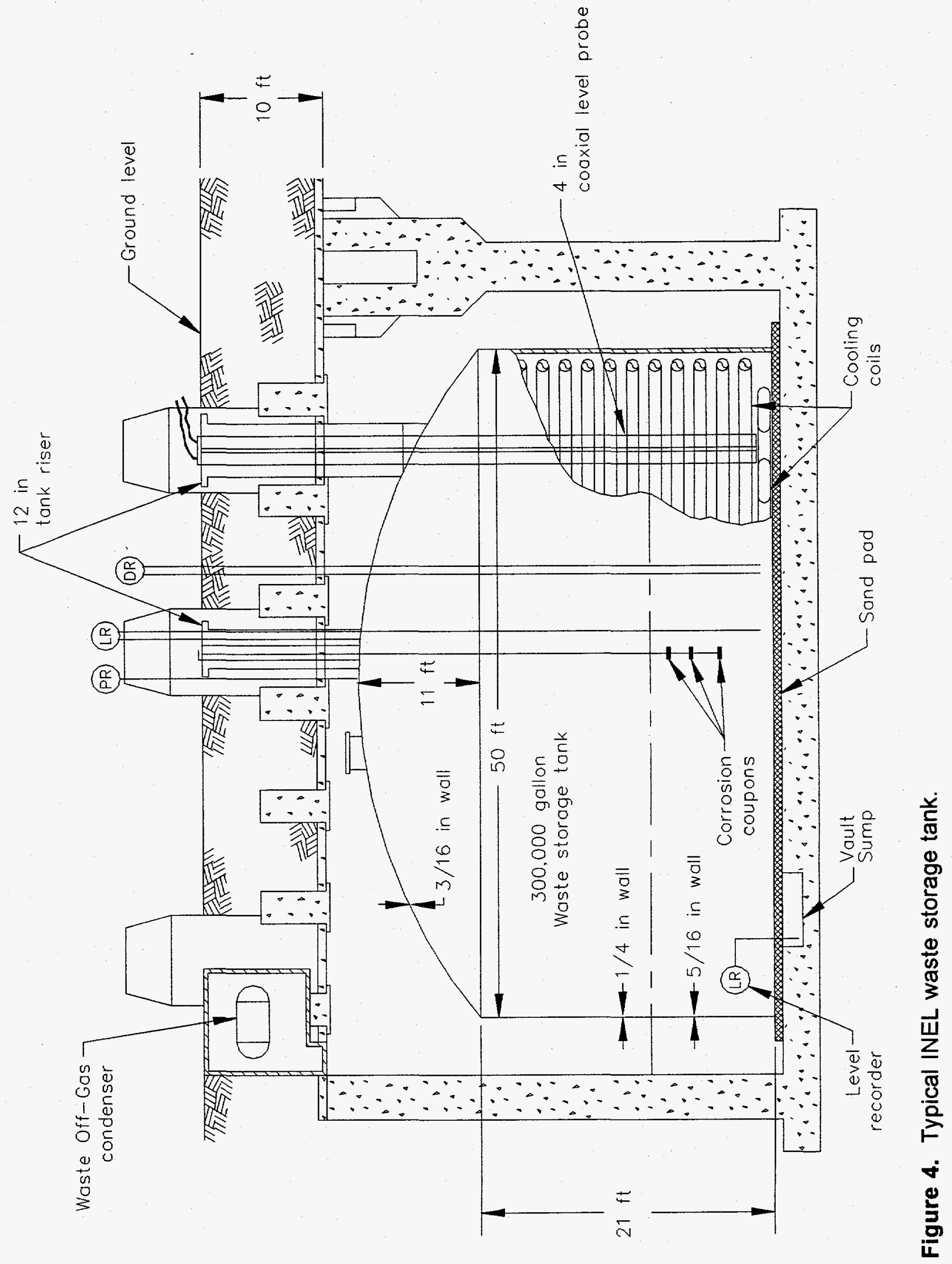




\section{ADDITIONAL REQUIREMENTS DOCUMENTS}

All materials used in fabrication, assembly, and supporting structures shall be in accordance with established codes and standards. Those deviations shall be identified and approved.

\subsection{Structural Materials Properties}

All material properties used in structural and corrosion resistance calculations shall be in accordance with the base / minimum properties of the American Society for Testing and Materials (ASTM) or the American Society of Mechanical Engineers (ASME) Boiler and Pressure Vessel Code, Section II, "Materials Specification." This standard shall be listed on fabrication/assembly drawings for each part.

Potential American Society for Testing and Materials (ASTM) codes:

ASTM A 240 Heat-Resisting Chromium and Chromium-Nickel Stainless Steel Plate, Sheet, and Strip

ASTM A $276 \quad$ Stainless and Heat-Resisting Steel Bars and Shapes

ASTM A 193/194 Alloy Steel and Stainless Steel Bolting Materials for High Temperature Service

ASTM B 209 Aluminum and Aluminum-Alloy Sheet and Plate

ASTM B 211 Aluminum and Aluminum-Alloy Bar, Rod, and Wire

\subsection{Welding}

All welding shall be performed with approved procedures by qualified welders. Weld procedures and welder qualifications shall be submitted for review. All welds shall be inspected using approved procedures by qualified weld inspectors. Weld inspectors shall be qualified to American Society for Nondestructive Testing (ASNT) Recommended Practice SNT-TC-1A or American Welding Society Certified Welding Inspector (AWSCWI). Weld inspector qualifications shall be submitted for review. All welds shall be visually inspected in accordance with AWS D1.1 for all steel and AWS D1.2 for aluminum, all for static conditions. Weld inspection requirements, which include the method of examination, extent of examination, and acceptance criteria, shall be identified on design drawings for review and approval. 
Potential American Welding Society (AWS) codes:

AWS D1.1 Structural Welding Code for Steel

AWS D1.2 Structural Welding Code for Aluminum

AWS D1.3 Structural Welding Code for Sheet Steel

AWS D9.1 Sheet Metal Welding Code

Potential American Society of Mechanical Engineers (ASME) welding code:

ASME Section IX Welding and Brazing Qualifications

\subsection{Electronics and Communications}

Potential Electronic Industrial Association protocols:

RS-232 Interface Between Data Terminal Equipment and Data Communication Equipment Employing Serial Binary Data Interchange

RS-281 Electrical and Construction Standards for Numerical Machine Control

RS-449 General Purpose 37 Position and 9 Position Interface for Data Terminal Equipment and Data Circuit Terminating Equipment Employing Serial Binary Data Interchange

RS-422-A Electrical Characteristics of Balanced Voltage Digital Interface Circuits

RS-423-A Electrical Characteristics of Unbalanced Voltage Digital Interface Circuits 


\subsection{Electrical}

Potential National Electrical Manufacturers Association (NEMA) codes:

ICS 1 Industrial Controls and Systems

ICS $6 \quad$ Enclosures for Industrial Controls and Systems

\subsection{Fire Protection}

National Fire Protection Association (NFPA) code:

70-93 National Electric Code

\subsection{Safety}

Potential Occupational Safety and Health Administration code:

29 CFR 1910 Occupational Safety and Health Standards

\subsection{Software}

Potential Institute of Electrical and Electronics Engineers (IEEE) codes:

829 IEEE Standard for Software Test Documentation

830 IEEE Guide to Software Requirements Specifications

1063 IEEE User Documentation

983 IEEE Guide for Software Quality Assurance Plans

Potential American Nuclear Society (ANS) codes:

ANSI/ANS 10.4 Verification and Validation of Scientific and Engineering Computer Programs 


\subsection{Design}

Potential American National Standards Institute code:

ANSI Y14.5M Dimensioning and Tolerancing

Potential American Welding Society code:

AWS A2.4 Weld Symbols

\subsection{Machining}

Potential American National Standards Institute codes:

ANSI B46.1 Surface Finishes

ANSI B1.1 Screw Threads 


\section{BIBLIOGRAPHY}

T.J. Samuel, C.M. Smith, B. Griebenow, G.A. Kiebel, B.A. Carteret, J.D. Potter, J. Engstrom, Technical Specification for the Light Duty Utility Arm System, WHC-S-124, Rev. 3, Westinghouse Hanford Company, August 26, 1994.

H. Jones and G. Cunliffe, Tank Riser Interface and Confinement and Tool Interface Plate, SPAR-LDUA-TM.029, Issue A, Spar Aerospace, September 30, 1994.

A.F. Pardini, Design Criteria for the Light Duty Utility Arm System End Effectors, WHC-SD-TD-CR-001, Draft, Westinghouse Hanford Company, September 15, 1994.

C.M. Smith, and D.L. Carroll, Functions and Requirements for the Light Duty Utility Arm Integrated System, WHC-SD-TD-FDR-003, Rev. 3, Pacific Northwest Laboratory, September 1994.

G. E. Barnes, Waste Dislodging and Conveyance End Effector Development for the INEL HLLW Heel Removal, INEL-94/0122, Idaho National Laboratory, October 1994.

K.J. Rebish, "Tank Farm Inventory - June, 1994," Letter \#KJR-02-94/JAN03-94, Idaho National Laboratory, January 1994.

DOE Order 5480.1B, "Environment, Safety, and Health Program For Department of Energy Operations".

INEL Radiological Controls Manual, Idaho National Engineering Lab.

INEL Architectural Engineering Standards, Idaho National Engineering Lab.

Idaho Chemical Processing Plant Industrial Safety Manual, IPM-IV-11, Idaho National Engineering Lab. 
Appendix A

\author{
Draft
}

Analysis List

A-1 


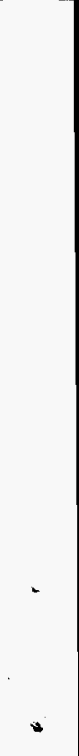


The following analysis list is currently desired to be completed on the waste samples taken from the tank. The list is broken down into the substance categories filtrate (filtered liquids), slurry (nonfiltered liquids), and solids (solids filtered out of slurry).

Filtrate Analysis

Toxic Characteristic Metals

Arsenic (As)

Barium $(\mathrm{Ba})$

Cadmium (Cd)

Chromium (Cr)

Lead $(\mathrm{Pb})$

Mercury $(\mathrm{Hg})$

Nickel (Ni)

Selenium (Se)

Silver (Ag)

\section{Other Metals}

Aluminum (Al)

Boron (B)

Calcium (Ca)

Iron (Fe)

Potassium (K)

Sodium $(\mathrm{Na})$

Strontium (Sr)

Zirconium ( $\mathrm{Zr}$ )
Radioactivity

Cesium $\left(\mathrm{Cs}^{134}\right)$

Cesium $\left(\mathrm{Cs}^{137}\right)$

Europium ( $\left.\mathrm{Eu}^{154}\right)$

Trans Uranium alphas Americium (Am)

Neptunium (Np)

Plutonium (Pu)

lodine $\left(1^{129}\right)$

Strontium $\left(\mathrm{Sr}_{\mathrm{T}}\right)$

Tritium $\left(H^{3}\right)$

Uranium (U)

\section{General Properties}

Acidity

Conductivity

Oxidation Potential (Filtrate or Slurry)

Particle Density

Specific Gravity

Anions

Chloride $(\mathrm{Cl})$

Fluoride $(\mathrm{F})$

Nitrate $\left(\mathrm{NO}_{3}\right)$

Phosphate $\left(\mathrm{PO}_{4}\right)$

Sulfate $\left(\mathrm{SO}_{4}\right)$ 


\section{Slurry Analysis}

\section{General Properties}

Flashpoint

Oxidation Potential (Filtrate or Slurry)

Radioactivity (Solids and Liquids Separately)

Semi-Volatile Organics

Volatile Organics

Settling Velocity

Total Organic Carbons (TOCs)

Undissolved Solids (UDS)

\section{Solids Analysis}

$\underline{\text { Total Metals }}$

Aluminum (Al)

Arsenic (As)

Barium (Ba)

Boron (B)

Cadmium (Cd)

Calcium (Ca)

Chromium (Cr)

Iron (Fe)

Lead $(\mathrm{Pb})$

Mercury $(\mathrm{Hg})$

Nickel (Ni)

Potassium (K)

Selenium (Se)

Silver (Ag)

Sodium $(\mathrm{Na})$

Strontium (Sr)

Zirconium ( $\mathrm{Zr}$ )

\section{Anions}

Chloride $(\mathrm{Cl})$

Fluoride $(\mathrm{F})$

Nitrate $\left(\mathrm{NO}_{3}\right)$

Phosphate $\left(\mathrm{PO}_{4}\right)$

Sulfate $\left(\mathrm{SO}_{4}\right)$
Radioactivity

Cesium $\left(\mathrm{Cs}^{134}\right)$

Cesium $\left(\mathbf{C s}^{137}\right)$

Europium ( $\left.\mathrm{Eu}^{154}\right)$

Trans Uranium alphas

Americium (Am)

Neptunium (Np)

lodine $\left({ }^{129}\right)$

Plutonium (Pu)

Strontium $\left(\mathrm{Sr}_{\mathrm{T}}\right)$

Uranium (U)

\section{General Properties}

Dry Bulk Density

Wet Bulk Density

Void Fraction (Bulk)

Emission Spectrometry

Particle Density

Particle Size and Distribution

Particle Photomicrograph 
Appendix B

Tool Interface Plate 
. 


\section{Appendix B \\ Tool Interface Plate}

The tool interface plate (TIP) is a quick disconnect system through which all end effector utilities are supplied. The following table outlines the services that are available for routing to the end effector.

\begin{tabular}{|c|c|c|c|}
\hline Utility & Number of Conductors & Size & $\begin{array}{c}\text { Connectorl } \\
\text { Rating }{ }^{1}\end{array}$ \\
\hline Signals & 30 twisted/shielded pairs & 22 AWG & Type D / 8 amps \\
\hline Power & 4 shielded triplets & 16 AWG & Type C / 25 amps \\
\hline Video & $275 \Omega$ coax & RG-187 & Type L / 3 amps \\
\hline General & $250 \Omega$ coax & $R G-174^{2}$ & Type L / 3 amps \\
\hline Water/air & 3150 psi hoses & 1/4" I.D. & -- \\
\hline
\end{tabular}

Notes: 1. The rating listed is the connector rating and NOT what the wire may be able to handle.

2. The coax cable listed is for the distance from the TIP to the top of the arm, other larger cable with the same impedance will be used for the rest of the distance to the at-tank enclosure.

The electrical connections are made through modular connectors from:

Hypertronics Corporation

16 Brent Drive

Hudson, MA 01749-2978

1-800-225-9228

Figure B-1 shows the schematic for the TIP signal wiring.

Figure B-2 shows the schematic for the TIP power wiring.

Figure B-3 shows the schematic for the TIP coax and identification wiring.

Figure B-4 gives the connector layout on the TIP along with the manufacturer's part numbers.

Figure B-5 provides some manufacturer information on the specific connectors used.

Figure B-6 shows the mechanical configuration of the two TIP halves. 


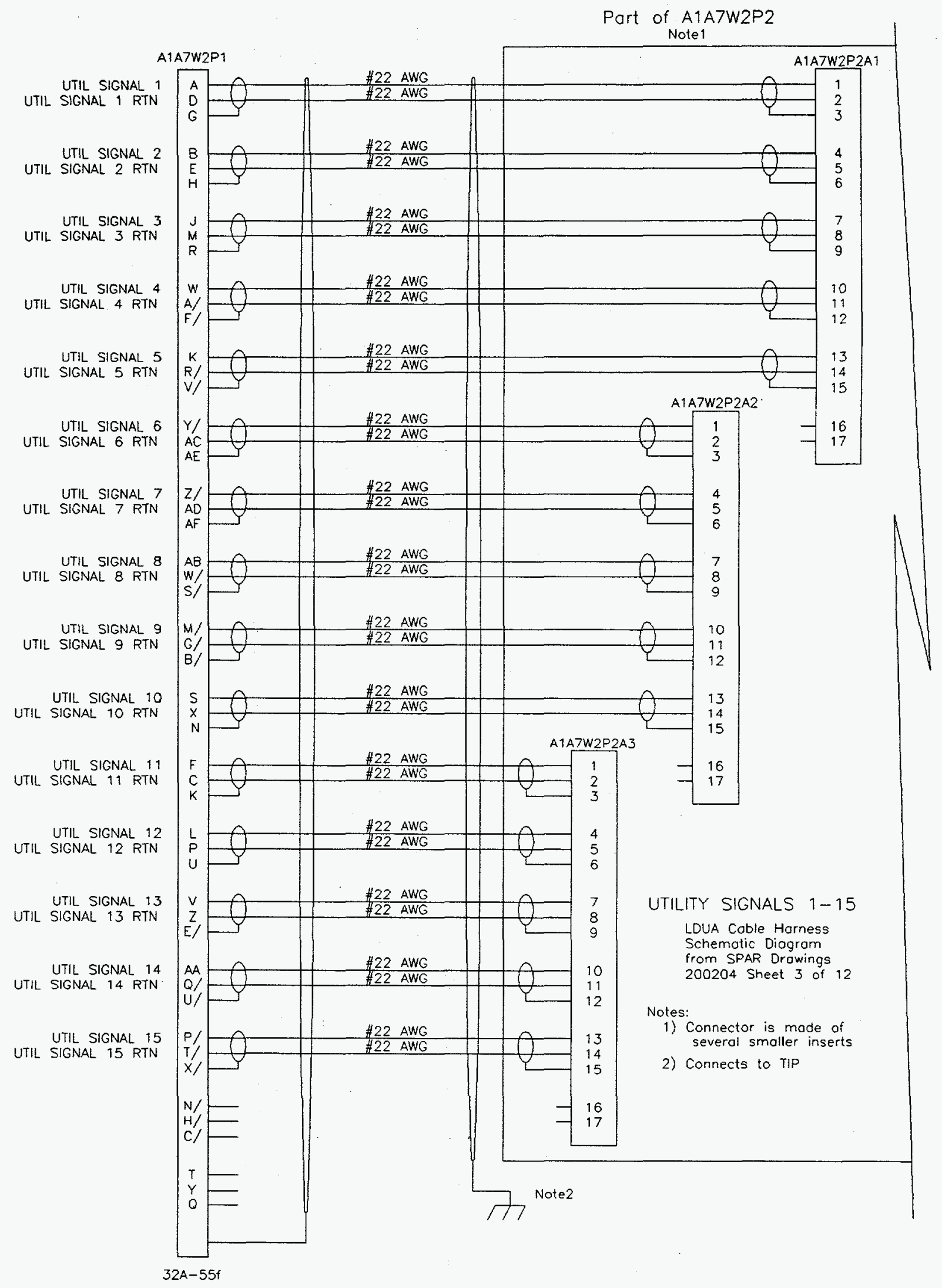

Figure B-1. TIP signal wiring schematic. 


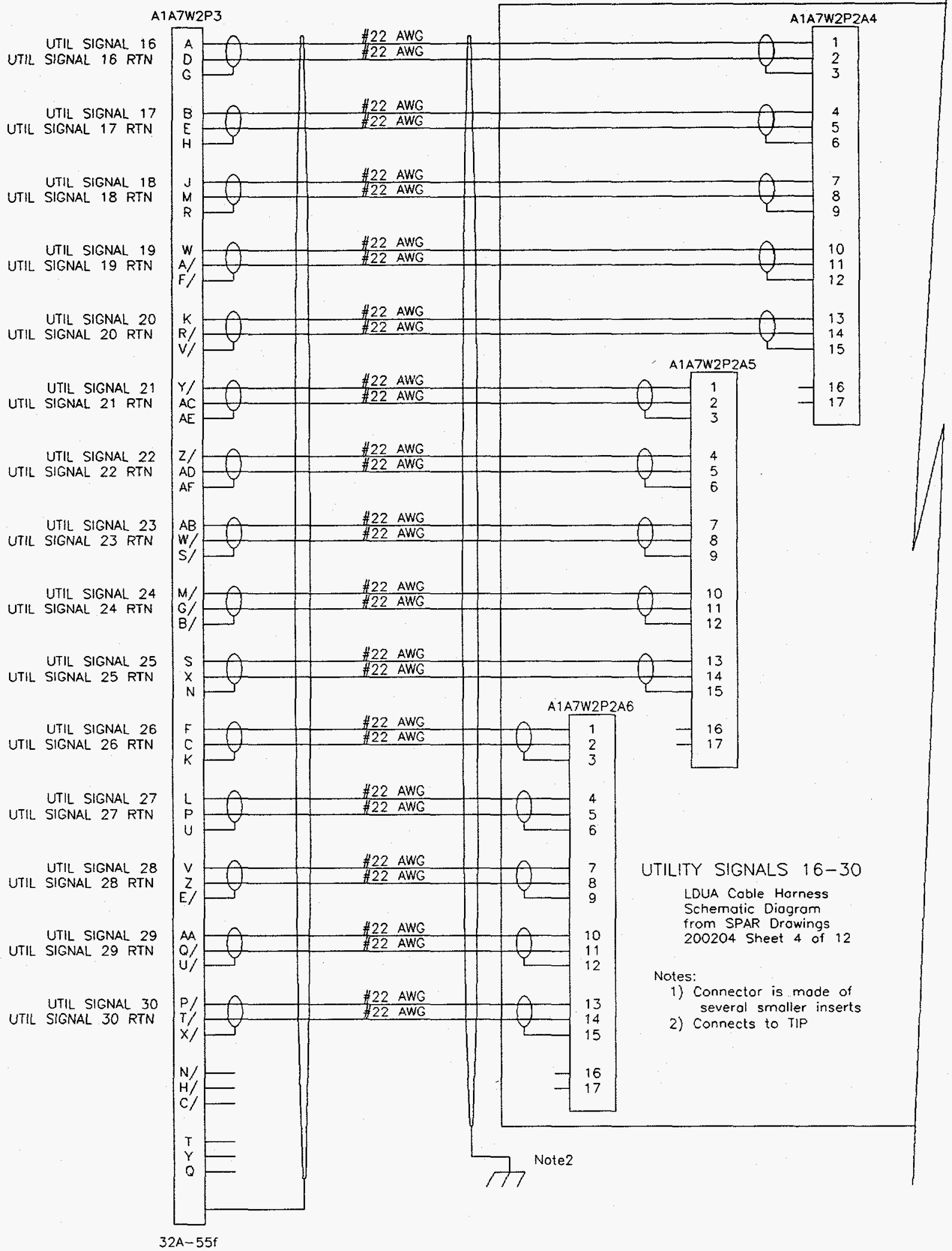

Figure B-1. (continued). 


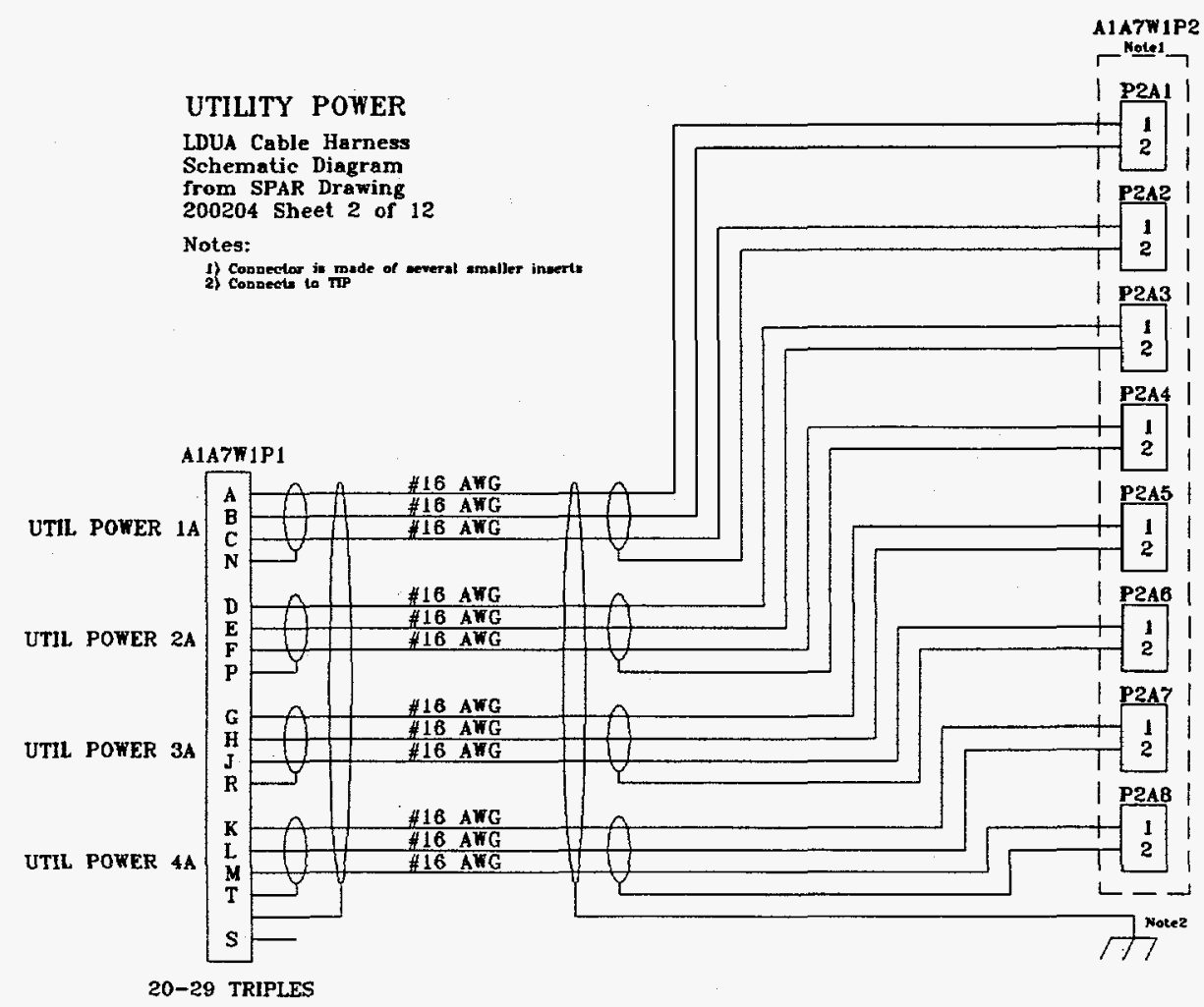

Figure B-2. TIP power wiring schematic.

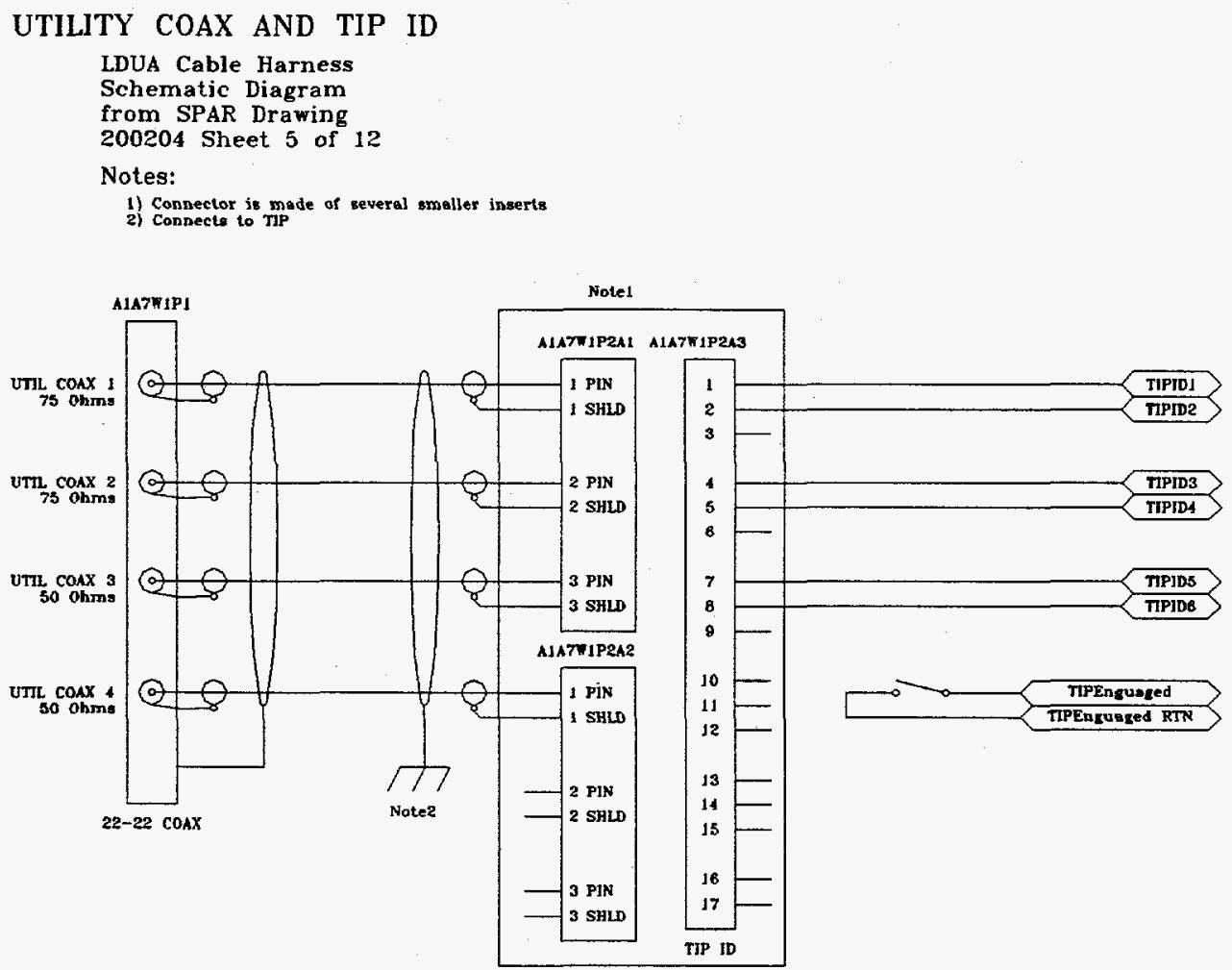

Figure B-3. TIP coax and identification wiring schematic. 


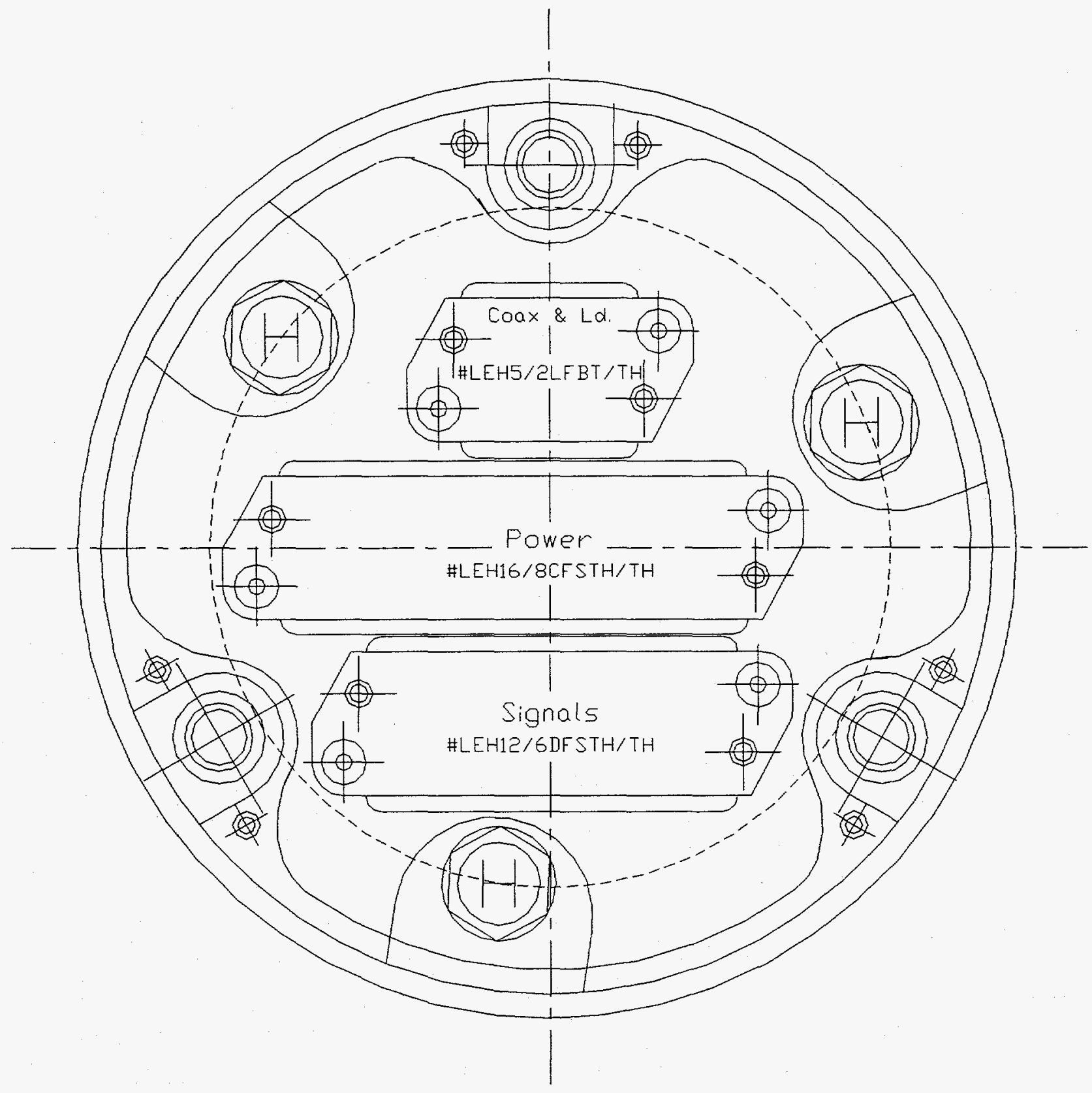

Figure B-4. TIP connector locations and manufacturer's part numbers. 
TYPE H 2 N Fla no. E102195 of File no. LAB3002

- Rack and panel with guides

Float mounting .049 (1.25) $\max$

- Weight, excluding modules plug $-1.902 .(53.2 \mathrm{gm})-4$ units $2.8 \mathrm{oz}(78.8 \mathrm{gm}) \odot 20$ units Prorate for other unit count weights receptacle $-1.602 .(45.2 \mathrm{gm}) 4$ units $2.50 z$. $(70.8 \mathrm{gm}) \bigcirc 20$ units

LPH

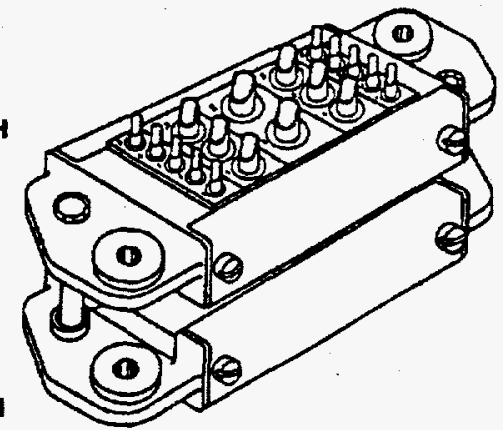

\section{ORDERING INFORMATION}

L EH 4

$\left[\begin{array}{l}\text { Frame Size: } 4 \text { - } 20 \text { units } \\ P=\text { Plug. } E=\text { Peceptacle }\end{array}\right.$

TYPE D Width is 2 unit
Plus:
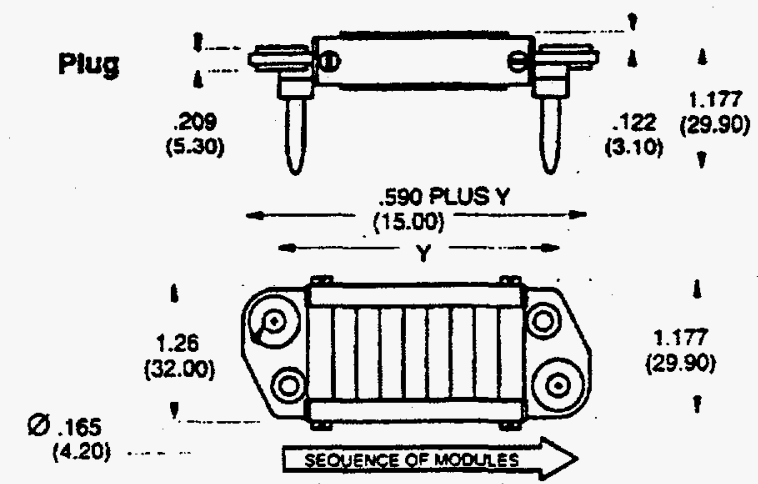

1.177

(29.90)

1

1.417

(36.00)

$\checkmark$

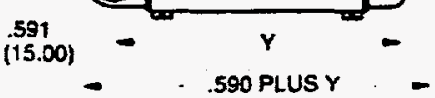

$512 \quad(15.00) \quad .433$

(11.00)

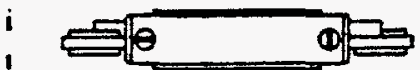

Notes:

1) See mounting dimensions, pg. L16

2) See ordering intormation, pg. L17 lor complete connectors

3) Dimensions in inches $(\mathrm{mm})$

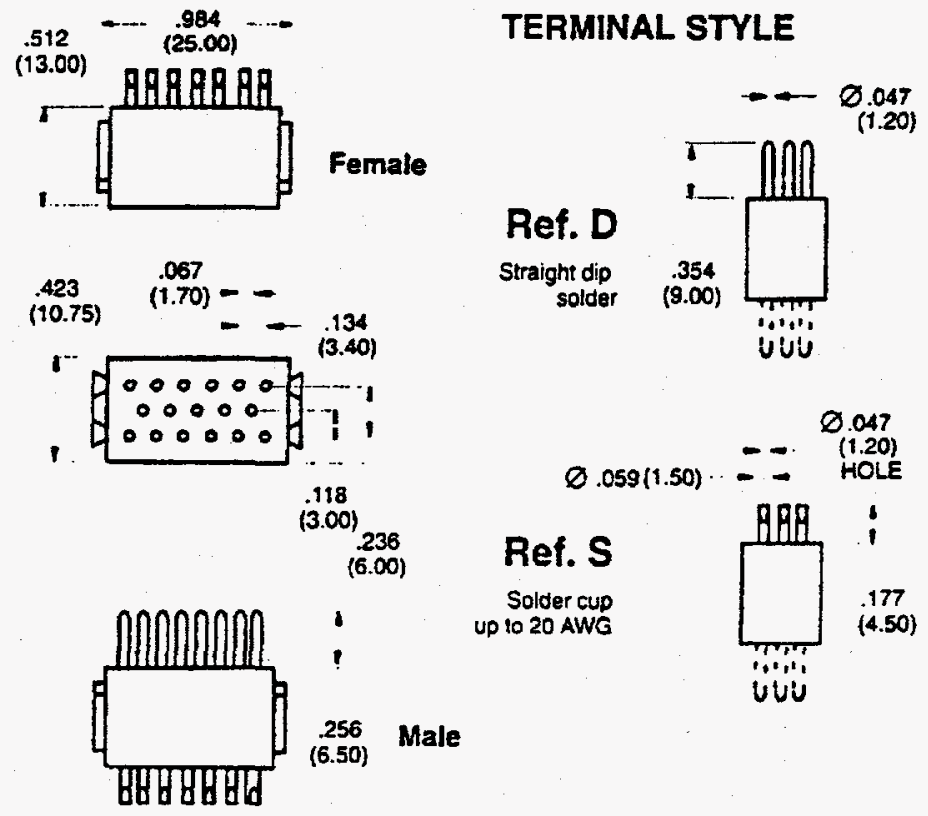

TERMINAL STYLE

1) For empty block, ordei LDHT.

2) For ordering information regarding modules assembled in frames, see pg. $L 17$. 3) Dimensions in inches (mm)
GENERAL SPECIFICATIONS

\begin{tabular}{|c|c|}
\hline Current Rating & 8 amps \\
\hline Contact Resistance & $<3.0$ millionms \\
\hline Extraction force & $1.0-4.50 z$ \\
\hline Contact Lile Cycles & $>100.000$ \\
\hline $\begin{array}{l}\text { Breakdown voltage } \\
\text { between contacts }\end{array}$ & $>1800$ V AMS \\
\hline Insulation Pesistance & $>10^{6}$ Megohms 900 VDC \\
\hline Temperature Rating & $-55^{\circ} \mathrm{C} t \mathrm{to}+125^{\circ} \mathrm{C}$ \\
\hline Insulator & Dialint-phthaiate \\
\hline $\begin{array}{ll}\begin{array}{l}\text { Contact } \\
\text { Malerial: }\end{array} & \text { (pin) } \\
\text { Plating: } & \text { (sacket) } \\
\end{array}$ & $\begin{array}{l}\text { Berass } \\
\text { gold over nickel } \\
\text { gold }\end{array}$ \\
\hline Approx. Weight & $\begin{array}{l}\text { M: } .31 \text { oz. }(9 \mathrm{~g}) \\
\text { F: } .45 \mathrm{oz} .(13 \mathrm{~g})\end{array}$ \\
\hline $\begin{array}{l}\text { Plating } \\
\text { Reference }\end{array}$ & $\begin{aligned} & T=10 \mu \text { in gold } \\
& \text { TH }=50 \mu \text { in gold } \\
& \text { TAH }=50 \mu \text { in gold on mating } \\
& \text { suriace \& gold fiash on socket } \\
& \text { codies (sockel only) }\end{aligned}$ \\
\hline
\end{tabular}

\section{ORDERING INFORMATION}

L D F S T

Figure B-5. TIP connector information. 
TYPE C : Width is 2 unit

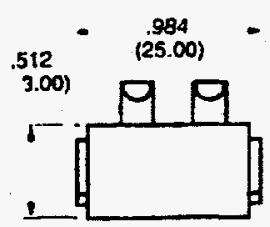

$(10.75)-\underset{(22.00)}{.823} \rightarrow$<smiles>O=Cc1ccccc1</smiles>

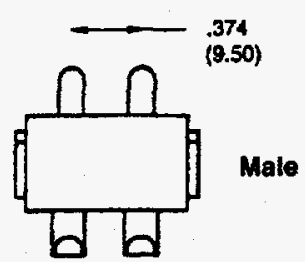

Notes:

1) For ompty block, order LCHT.

2) For ordering information regarding modules assembled in frames, see pg. L 17

3) Dimensions in inches (mm)

TYPE Width is 1.5 unit

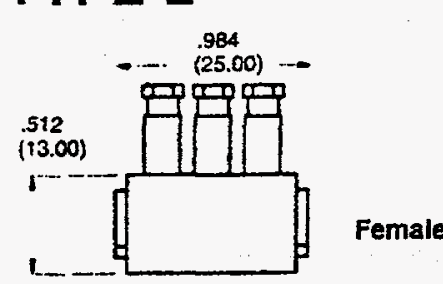

$$
.315-(22.00) \cdots
$$

$(8.00)$

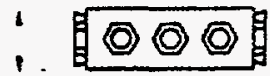

(O) $(0)$

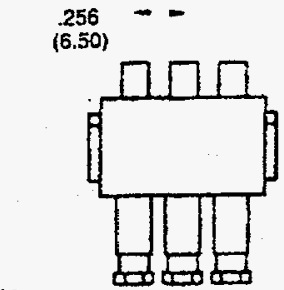

Notes:

1) For ordering intormation regarding modules assemblad in frames, see pg. L 17.
TERMINAL STYLE .

Ref. D

Straignt dip solder

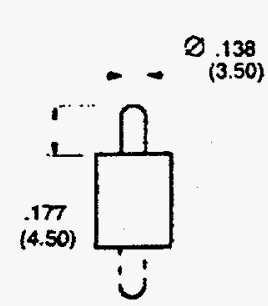

Ref. S

\section{$S$} Solder cup
to 10 AWG

$$
\underset{i j}{14.50)}
$$
Q.138 (3.50)
TERMINAL STYLE

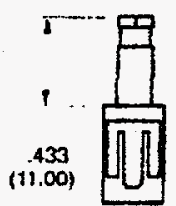

Ref. A

Cable size: $\varnothing .08(2.00)$ max $50 \Omega=R G 178$ OR RG 196

Ref. B

Cable size: $0.12(3.00)$ max $50 \Omega=8 G 174$, RG188 or $9 G 316$

$$
75 \Omega=R G 179 \text { or } \mathrm{AG} 1 \mathrm{~B} 7
$$

\begin{tabular}{|c|c|}
\hline Current Pating & 25 amps \\
\hline Contact Resistance & $<.8$ milliohms \\
\hline Extraction Force & $4-32$ oz. \\
\hline Contact Life Cycles & $>100.000$ \\
\hline $\begin{array}{l}\text { Breakdown voltage } \\
\text { between contacts }\end{array}$ & >3000V AMS \\
\hline Insulation Pesistance & $>10^{6}$ Megohms 500 VDC \\
\hline Temperature flating & $-55^{\circ} \mathrm{C}$ to $+125^{\circ} \mathrm{C}$ \\
\hline Insulator & Diallht-phthalate \\
\hline \begin{tabular}{ll|} 
Contact & (pin) \\
Materiat: & (socket) \\
Plating: & \\
\end{tabular} & $\begin{array}{l}\text { BaCu wires + brass body } \\
\text { gold over nicket }\end{array}$ \\
\hline Approx. Weight & $\begin{array}{l}M: .43 \text { oz. }(12.2 \mathrm{~g}) \\
F: .31 \text { oz. }(8.90)\end{array}$ \\
\hline $\begin{array}{l}\text { Plating } \\
\text { Reference }\end{array}$ & $\begin{aligned} & r=10 \mu \text { in gold } \\
& \text { TH }=50 \mu \text { in gold } \\
& \text { TAH }=5 \text { sylin gold on mating } \\
& \text { surface } 8 \text { gold llash on socke! } \\
& \text { bodies (socket only) }\end{aligned}$ \\
\hline
\end{tabular}

Male

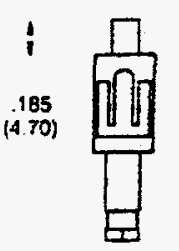

\section{ORDERING INFORMATION}

L C F S T

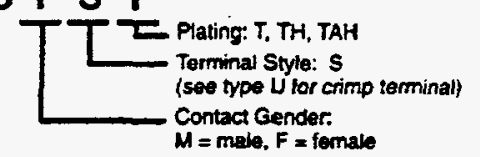

$M=$ male. $F=$ femain

\begin{tabular}{|c|c|}
\hline Current Rating & 3 amps \\
\hline Standing Wavs Ratio & $<1.1=3.9 \mathrm{GHz}$ \\
\hline Extraction Force & $5.3-28$ az. \\
\hline Contact LHe Cycles & $>5000$ \\
\hline $\begin{array}{l}\text { Breakdcwm voltage } \\
\text { internal vs. extemal: } \\
\text { Contacts/Rails: }\end{array}$ & $\begin{array}{l}>1000 \text { V RMS } \\
>15 c 0 \text { RMS }\end{array}$ \\
\hline Insulation Ressistance & $>10^{6}$ Megonms 500 VOC \\
\hline Temperature Rating & $-55^{\circ} \mathrm{C} 10+125^{\circ} \mathrm{C}$ \\
\hline insulator & Diallyl-ptrihalate \\
\hline $\begin{array}{l}\text { Contect } \\
\text { Material: } \\
\text { Plating: }\end{array}$ & $\begin{array}{l}\text { BeCu wires, trass } \text { teflon } 8 \\
\text { Gold over nickel on wires } \\
\text { center contact. siker on body }\end{array}$ \\
\hline Approx. Weight & $\begin{array}{l}\text { M: } .31 \text { oz. }(8.9 \mathrm{~g}) \\
\text { F: } .39 \mathrm{cz} .(11 \mathrm{~g})\end{array}$ \\
\hline Plating Relerence & $\begin{aligned} T= & 10 \mu \text { in gold } \\
& \text { 3oopin silver }\end{aligned}$ \\
\hline
\end{tabular}

For 50 or $75 \Omega$ applications

\section{GENERAL SPECIFICATIONS}

\section{ORDERING INFORMATION}

L L F A T

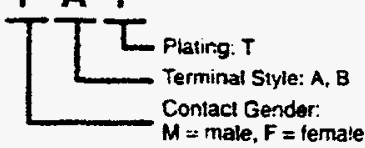

Figure B-5. (continued). 


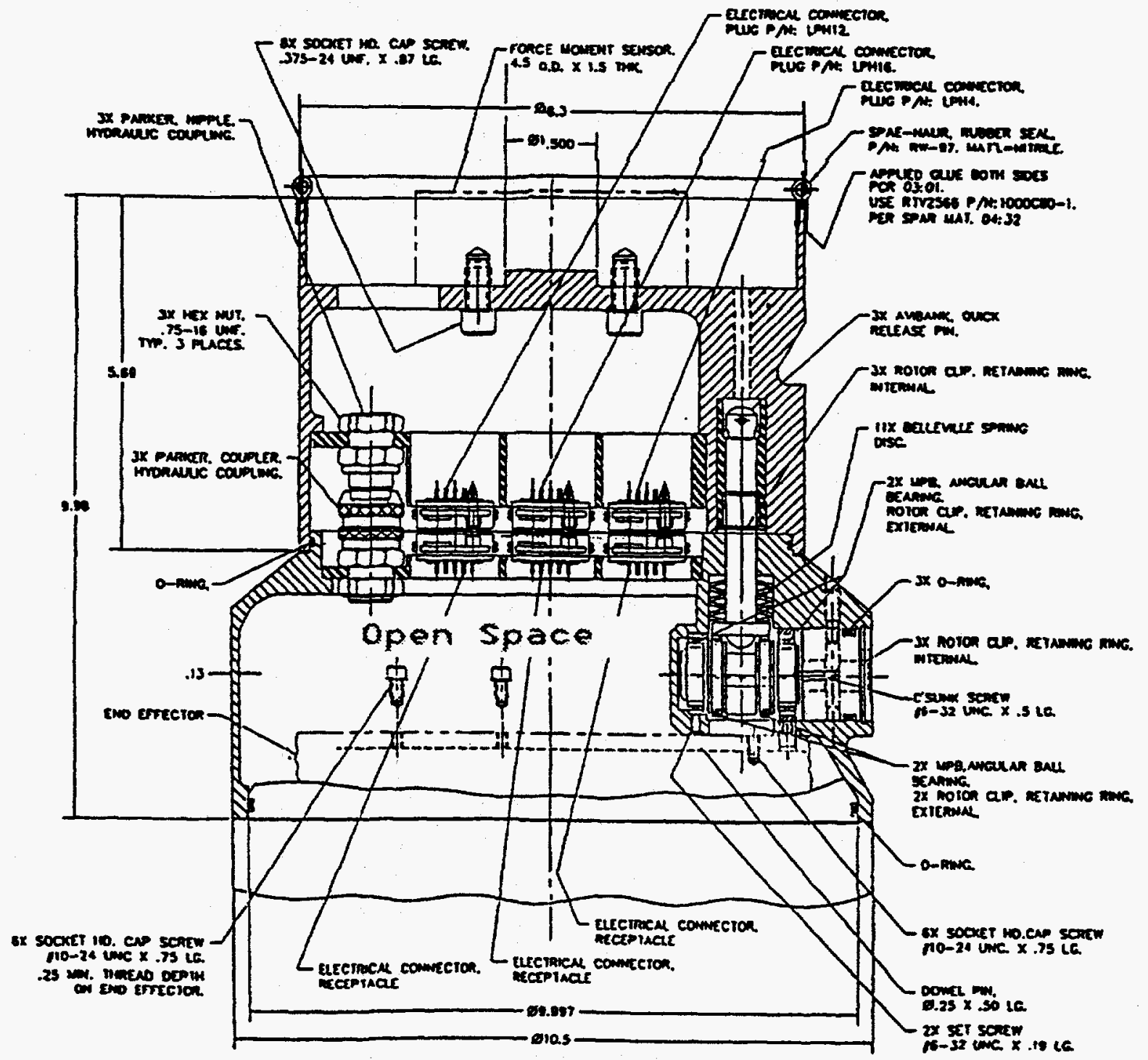

Figure B-6. TIP mechanical dimensions. 